\title{
Financial Satisfaction and (in)formal Sector in a Transition Country
}

\author{
Ada Ferrer-i-Carbonell • Klarita Gërxhani
}

Accepted: 21 July 2010/Published online: 10 August 2010

(C) The Author(s) 2010. This article is published with open access at Springerlink.com

\begin{abstract}
This paper examines the relationship between working in the formal or informal sector and self-reported individual financial satisfaction in a country in transition. It does so by allowing for individual heterogeneity in terms of perceived financial insecurity and tax morale. The empirical analysis uses a dataset for Albania, a country in transition. The method applied is the 'self-administered questionnaire', which combines personal contacts with written questionnaire. The results indicate that, for most individuals, working in the informal sector has negative effects on their self reported financial satisfaction. For some individuals, however, this effect is positive. The characteristic defining these two groups of individuals is their attitude towards the perceived financial insecurity related to not paying taxes. These findings have important implications, in particular for transition countries with large informal sectors. Given the involuntary participation in the informal sector in these countries, the majority of individuals working in this sector will remain financially dissatisfied as long as they have no other social safety net.
\end{abstract}

Keywords Financial satisfaction · Informal sector $\cdot$ Tax morale $\cdot$ Transition

\section{Introduction}

An important episode in the previous century was the rise and fall of communist economies in Central and Eastern Europe and the Baltic states. The collapse of these economies led to the emergence of so-called transition countries, which are characterized by rapid economic

\footnotetext{
A. Ferrer-i-Carbonell ( $\square)$

Institut d'Anàlisi Econòmica (IAE-CSIC), Campus UAB, 08193 Barcelona, Spain

e-mail: ada.ferrer@iae.csic.es

K. Gërxhani

Faculty of Social and Behavioural Sciences, University of Amsterdam,

Amsterdam, The Netherlands

K. Gërxhani

Faculty of Economics and Business, and Tinbergen Institute, University of Amsterdam,

Amsterdam, The Netherlands
} 
and institutional change. This transformation has been accompanied by the appearance of a substantial informal sector. From an economic sociology perspective, the informal sector is important for social (in)equality through both the re-allocation of resources it causes and its impact on individuals' welfare. This paper focuses on the latter.

Early studies argue that average individual earnings in the informal sector are lower than in the formal sector (Harris and Todaro 1970; Merrick 1976; Kugler et al. 1979; Bourguignon 1979; Banerjee 1982; Heckman and Hotz 1986; Pradhan and van Soest 1995; Pisani and Pagán 2003). Thomas (1990) presents evidence that this mainly holds for less developed countries. Other studies suggest that the earnings distributions in the formal and informal sectors have substantial overlap (Fields 1990), so that the differences may be smaller than is commonly thought (Charmes 1990). These findings have identified two subsectors within the informal sector. One is called the 'upper-tier informal sector'. This is characterized by limited-entry and high wages (relative to the formal sector), and is preferred by workers to formal sector employment. The other is called the "easy-entry informal sector', which consists of employment that is characterized by free-entry and low wages. Workers consider the latter to be undesirable relative to formal sector employment. Based on this distinction, Fields (1990) reports that individuals working in the upper-tier informal sector have voluntarily moved there from the formal sector and are happy about their choice. For these individuals, the disadvantages of working in the informal sector are outweighed by the advantages. Individuals who participate in the easy-entry informal sector are dissatisfied with working in the informal sector and are typically looking for jobs in the formal sector.

In other words, other factors than (net) income may affect the well-being associated with the informal sector compared to the formal sector. For example, aside from the financial advantage of not paying taxes (e.g., Hansson 1982), the informal sector sometimes provides more flexibility and opportunities for individual initiative and creativity than the formal sector (De Grazia 1982; Renooy 1990; Marcouiller et al. 1997). However, in addition to lower earnings, working in the informal sector may have other disadvantages: workers often experience worse working conditions, face higher job insecurity, have no labor contract and, as a consequence are excluded from various social benefits. ${ }^{1}$ For these reasons, a comparison based on subjective measures of well-being may be preferable to direct comparisons of net income. In this paper, we present such a comparison in an attempt to better understand the motivations behind working in the informal sector and the consequences thereof for individual welfare.

Though the existing literature touches upon welfare differences between the two sectors, a systematic analysis is missing. Income is often used to compare individuals across sectors, but as mentioned above, there is more to welfare than just income (e.g., (un)certainty about the future and (lack of) social security). In this paper, we use instead a broader concept of economic welfare, which is captured by individuals' own evaluation of their financial situation, i.e., their financial satisfaction. Reported financial satisfaction is a measure of the contentment that individuals derive from their economic situation and it is therefore correlated but not identical to individuals' income and wealth. Financial satisfaction relates to how individuals perceive their economic situation, which typically depends on the individual socio-economic situation and on how their financial situation compares to the past, to other individuals in the society, and to what individuals expect in the future. This paper fills the existing gap by offering a first (econometric) analysis of the

\footnotetext{
1 Nevertheless, working in the informal sector is often preferred to being unemployed (De Grazia 1982; Kesner-Skreb 1997; Gërxhani 2004b).
} 
effect of working in the (in)formal sector on individual self-reported financial situation. It is through such an analysis that we are able to systematically understand individual motivations of working in the informal sector and their implications for individuals' financial satisfaction.

The empirical analysis uses a dataset for Albania, a country in transition. After the collapse of communism, a combination of economic, social and institutional factors created suitable conditions for the informal sector to be prevalent in Albania (Gërxhani and Schram 2006). ${ }^{2}$ Moreover, individual involvement in the informal sector in this country is not voluntary. This is due to a limited number of jobs available in the formal sector combined with trivial and short-termed financial support by the Albanian welfare system. As shown by Gërxhani (2004b), this lack of choice is a fundamental difference between the informal sector in developed countries and that in transition countries like Albania. In the latter countries, 'survival' plays an important role in the decision to participate in the informal sector. ${ }^{3}$ In another study, on the dichotomous sectoral composition of labor in Nicaragua, Pisani and Pagán (2003) argue that "unlike developed countries which have a functional social safety net for unemployed people to 'wait' or queue for formal sector employment, Nicaragua has virtually no social safety net; this compels potential formal sector job seekers to work in the informal sector (which acts as the de facto social safety net) while awaiting formal sector employment." (p. 574). Clearly, transition (undeveloped) countries provide special cases. This is not only related to their large shadow economies, but also to the fact that most individuals in these countries are often constrained to work in the informal sector which is characterized by labor intensive and low technology. As a consequence, the allocation of resources and success within the society will be distorted, resulting in support rather than moderation of social inequality (Bromley and Gerry 1979; Ditton and Brown 1981; Moser 1994; Leonard 2002). Hence, individual motivations for working in the (in)formal sector are expected to have important implications for individual welfare and social (in)equality in such countries.

Finally, this paper takes the analysis one step further by recognizing that individuals are not homogenous economic agents with identical perceptions of their own welfare. In the empirical application, it identifies two groups of individuals, distinguished by their attitudes towards taxes. An important distinction between working in the formal and informal sector is whether or not individuals pay taxes. Individuals may, however, differ in (1) how they perceive the financial consequences of (not) paying taxes and in (2) their beliefs about contributing to public goods by paying taxes. By allowing for these differences in individual motivations to work in the (in)formal sector, the analysis provides a more accurate explanation for heterogeneity in financial satisfaction.

The remainder of this paper is structured as follows. Section 2 introduces the empirical approach. This involves a description of the question used to capture financial satisfaction, an explanation of the econometric approach, and a characterization of the data. Section 3 presents and discusses the results. Section 4 concludes.

\footnotetext{
2 The average size of the shadow economy in Albania was estimated to be $33.4 \%$ in 1999/2000 (Schneider 2005). This same study shows that the size of the shadow economy is on average higher in transition countries than in developed countries.

3 The fact that formal and informal sectors are often found to be complementary in transition countries is another indication of the survival aspect of the informal sector in these countries. A broader discussion can be found in Schneider and Enste (2000).
} 


\section{The Empirical Approach}

\subsection{Subjective Measures}

Psychologists have measured individual well-being by means of subjective questions since the late 1960s, starting with Cantril (1965), Wilson (1967) and Bradburn (1969). An overview of this literature is presented in Kahneman et al. (1999). More recently, many economists have made use of subjective questions on, among others, welfare (financial satisfaction), well-being, and health satisfaction, to address a wide range of scientifically and politically relevant questions. ${ }^{4}$ Subjective questions ask individuals about their life satisfaction in general or with respect to various domains of life in particular, such as housing, health, or their financial situation. The most relevant characteristic of the subjective measures is their focus on individual perceptions rather than on their objective situation. This implies that individuals' subjective evaluation of their own circumstances can change even when the objective situation remains the same. This can happen, for example, if individuals adapt to past income changes or to health impediments.

The focus of this paper is the consequences for financial satisfaction of working in the formal or informal sector, hence the following question is used:

"How satisfied are you with the financial situation of your household?"

Individuals are asked to evaluate their satisfaction on a $0-10$ scale, where 0 stands for 'totally dissatisfied' and 10 for 'totally satisfied'. This information will be referred to as individual financial satisfaction. Financial satisfaction reflects individuals' perceptions of their economic situation. This means that two individuals who have the same income can experience different financial satisfaction levels. The analysis presented here sheds light on the question of whether-over and above its implications for income-the sector in which one works affects financial satisfaction. Van Praag and Ferrer-iCarbonell (2004) make use of the same question when studying the extent of poverty in Russia. $^{5}$

The empirical analysis of financial satisfaction-as for any subjective measurerequires two main assumptions, which we consider warranted. First, individuals are able and willing to evaluate their own financial satisfaction in a questionnaire. Second, the answers to the financial satisfaction question are interpersonally comparable. In other words, it is assumed that different individuals understand and respond to the financial question in similar ways. It is beyond the scope of this paper to discuss these two assumptions. A detailed discussion is provided in Ferrer-i-Carbonell and Frijters (2004) and Senik (2005).

\footnotetext{
${ }^{4}$ Studies include Clark and Oswald (1994); Kapteyn (1994); Ng (1997); Oswald (1997); van Praag and Frijters (1999); Pradhan and Ravallion (2000); DiTella et al. (2001); Easterlin (2001); Ferrer-i-Carbonell and van Praag (2002); Frey and Stutzer (2002); Ravallion and Lokshin (2002); Torgler (2003); van Praag et al. (2003); Ferrer-i-Carbonell and Frijters (2004); Frijters et al. (2004); Ferrer-i-Carbonell (2005); and Torgler and Schneider (2005).

${ }^{5}$ Ravallion and Lokshin (2002) use another subjective welfare question, called the Economic Welfare Question, to explain the large differences between objective and subjective poverty in Russia. Other subjective measures of poverty are based on the Income Evaluation Question, the Minimum Income Question, and the Minimum Spending Question (see, e.g., van Praag 1971; Kapteyn et al. 1988; van Praag et al. 1997; Garner and Short 2003; and Gustafsson et al. 2004).
} 


\subsection{The Empirical Model}

At the theoretical level, it is important to distinguish between giving cardinal or ordinal meaning to the satisfaction question. When individual answers to the financial satisfaction question are considered cardinal, it is assumed that the distance between satisfaction categories is identical, i.e., the distance between a 4 and 5 is the same as between a 5 and a 6 . This implies that an individual reporting an ' 8 ' is twice as satisfied as one who reported a ' 4 '. If the individual responses to financial satisfaction are considered ordinal, only the ordering of the individuals in a satisfaction scale is known but not the magnitude of the differences. At the empirical level, however, this distinction does not appear to be relevant. Linear and ordered categorical models are used indiscriminately, as they provide very similar results in terms of the trade-offs between variables (Ferrer-i-Carbonell and Frijters 2004; van Praag and Ferrer-i-Carbonell 2004, Chap. 2).

In this paper, we consider the answers to the financial satisfaction question as cardinal and consequently use an OLS estimator. This allows us to clearly interpret the interaction terms that are included in the main regression (cf. Table 1). ${ }^{6}$

Individual financial satisfaction is described by the following empirical model:

$$
\mathrm{FS}=\alpha+\beta \operatorname{Ln}(y)+\gamma I+\delta X+\varepsilon
$$

where FS is the reported financial satisfaction on a $0-10$ scale. Equation 1 shows that the financial satisfaction is explained by whether an individual works in the informal sector $(I)$, by the household (monthly) net income $(y)$, and by a set of socio-economic and demographic variables $(X) . I$ is a dummy variable that takes a value 1 if the individual works in the informal sector, and 0 if (s)he works in the formal sector. The household income is taken in logarithmic form. This specification is chosen to reflect a diminishing marginal utility of income. The error term $\varepsilon$ represents the part of FS that cannot be explained.

\subsection{Heterogeneous Individuals}

One main characteristic of individuals working in the informal sector is that they do not pay taxes, which as such excludes them from public insurance schemes. ${ }^{7}$ Given that financial satisfaction partly depends on individuals' expectations about their future situation, the degree of perceived financial insecurity related to working in the informal sector may have an impact on individual financial satisfaction. Assuming that for most individuals public insurance schemes are the only source of social safety net, one would expect a lower financial satisfaction for individuals working in the informal sector than for those working in the formal sector.

The degree of perceived financial insecurity is captured in our data set by the answer to the question on whether individuals (dis)agree (on a 5-point scale) with the following statement: "Not paying social and health insurance today would cause serious financial problems for me in the future (e.g., no pension benefits)". Individuals working in the informal sector who disagree with this statement may either not understand that not paying social security taxes today means not receiving benefits in the future or may have other

\footnotetext{
${ }^{6}$ We obtained similar results when we regressing Financial Satisfaction with an Ordered Probit (OP) estimator.

7 In Albania, our case study, payment of social and health insurance premiums is mandatory and is directly subtracted from income together with other taxes. In addition, an individual is entitled to benefits only if (s)he has contributed to the scheme (see Beqja 2002).
} 
means to provide for themselves in the future (e.g., through family members or accumulated wealth). In the latter case, individuals in the informal sector may think that a pooled insurance is less beneficial to them than their own private way of insuring the future. In other words, they perceive a low degree of financial insecurity when working in the informal sector and thus not paying taxes may even positively affect their current financial satisfaction. In contrast, individuals working in the informal sector who agree that there will be negative financial consequences in the future of not paying taxes today, may have no other means of insuring their future. As such, they perceive a high degree of financial insecurity and will probably report a lower financial satisfaction than if they were to work in the formal sector.

Another important aspect related to informal sector working and the associated nonpayment of taxes is tax morale (see Alm and Torgler 2005, 2006; Alm et al. 2006; Feld and Torgler 2006; Torgler and Schneider 2007; and Torgler 2007). Tax morale is often defined as "individuals' willingness to pay taxes or, in other words, the moral obligation to pay taxes or the belief in contributing to the society by paying taxes" (Cummings et al. 2009). Many studies argue that tax morale does not only depend on one's upbringing but also on the specific institutional context, including for example, experience with tax authorities, interaction with other taxpayers, the constitutional environment, enforcement mechanisms, and insecurity of property rights (Frey 1989; Alm et al. 1992; Feld and Frey 2002; Schneider and Enste 2003; Torgler 2003; Frey and Torgler 2007; Bird et al. 2008; Torgler and Schneider 2009). In other words, tax morale reflects individuals' willingness to contribute to society through taxes, which goes hand in hand with the belief that taxes are useful. This implies that tax morale is highly correlated with individuals' willingness to contribute to public goods. ${ }^{8}$

Based on the information included in the data set at hand, we proxy tax morale by whether individuals (dis)agree (on a 5-point scale) with: "People should pay taxes because if they do, they will benefit from them (e.g., better roads, more parks, and more schools)". Individuals, who agree that people should pay taxes because of the public benefits involved, reveal a high level of tax morale. We postulate that for these individuals, paying taxes (i.e., contributing to public goods) can positively affect their financial satisfaction in two ways: (1) they themselves enjoy a larger provision of public goods; (2) altruistic individuals who contribute to public goods will experience a utility gain due to contributing to the welfare of others, i.e., the economic burden of having to pay taxes may be compensated by the pleasure of contributing to the group's welfare. The last is known as the 'warm-glow' effect, described by Andreoni (1990: 473) as the utility gain "from the act of giving". For individuals working in the informal sector, this means that those with high tax morale may enjoy a low level of financial satisfaction, as they are unable to contribute to public goods. For individuals with low tax morale, however, working in the informal sector and thus not paying taxes should not have any impact on their financial satisfaction.

To sum up, we hypothesize that the effect of working in the (in)formal sector on reported financial satisfaction will depend on individuals' perceived financial insecurity and their tax morale. In order to test this hypothesis, the empirical analysis distinguishes between various types of individuals (defined by their perceived financial insecurity and their tax morale), for whom the impact of working in the (in)formal sector on financial satisfaction may differ.

\footnotetext{
${ }^{8}$ Experimental evidence shows that one reason why people contribute to taxes is because they finance public goods (e.g., Becker et al. 1987; Alm et al. 1992).
} 
This hypothesis is operationalized by including two new variables in Eq. 1: one indicating the degree of agreement with the statement that not paying taxes today gives financial insecurity in the future; and the other indicating the degree of tax morale (i.e., the degree of agreement with the statement that people should pay taxes because of the public benefits involved). These two variables (called FI and $H T m$, respectively) can take 5 values, ranging from 'strongly disagree' $(=1)$ to 'strongly agree' $(=5) .{ }^{9}$ In the empirical analysis we attach cardinal value to both variables, the perceived financial insecurity related to not paying taxes and the tax morale. ${ }^{10}$ Financial satisfaction is regressed including two interaction terms between working in the informal sector and the two variables, $F I$ and $H T m$. Additionally, the perceived financial insecurity and the tax morale are included separately in the analysis so as to differentiate between their indirect effects through working in the informal sector and their direct effects on financial satisfaction.

Financial satisfaction is now explained by:

$$
\mathrm{FS}=\alpha+\beta \operatorname{Ln}(y)+\gamma I+\varphi(I \times F I)+\phi \mathrm{FI}+\pi(I \times H T m)+\kappa H T m+\delta X+\varepsilon
$$

The effect that working in the informal sector has on the financial satisfaction is described by $\gamma ;(\gamma+\varphi)$, or $(\gamma+\varphi+\pi)$ depending on individuals' perceived financial insecurity related to not paying taxes and their tax morale. If these three coefficients are identical, all the individuals are affected in the same way. For completeness, the empirical analysis includes a third specification in which we exclude the interaction terms from Eq. 2. This specification allows us to identify whether the differences (if any) in $\gamma$ between Eqs. 1, 2 are related to the perceived financial insecurity and tax morale variables or to the interaction terms between these variables and working in the informal sector.

\subsection{Endogeneity of the Sector Choice}

An empirical concern is that the sector choice may be endogenous. Here we consider three potential ways (two from the supply side and one from the demand side) in which the assumed exogeneity of sector choice may affect the extent to which the results can be interpreted.

From the supply side, endogeneity occurs if individuals self-select themselves into either the formal or informal sector. Most of the previous recent research models tax evasion and occupational decisions as an individual choice (see, for example, Watson 1985; Jung et al. 1994; Schroyen 1997). While this research refers to developed countries, the literature about less developed countries argues that working in the informal sector is not a matter of choice in a transition country like Albania (cf. Sect. 1). In this paper we empirically test this hypothesis. If there were a free choice of sector, individuals would choose the sector where they obtain a higher financial satisfaction. ${ }^{11}$ In this case, one would expect individuals who do not perceive important financial consequences in the

\footnotetext{
9 The frequency distribution of the perceived financial insecurity is: $82 \%$ strongly agree with the statement, $11 \%$ mildly agree, $4 \%$ are neutral, $1 \%$ mildly disagree, and $2 \%$ strongly disagree. For tax morale, this distribution is $68,17,9,3$ and $3 \%$, respectively.

${ }^{10}$ The results reported in the empirical analysis (cf. Sect. 3.2) are qualitatively the same when classifying the respondents into two groups only, i.e., those having a high (low) tax morale and perceiving a high (low) degree of financial insecurity related to taxes. Individuals were classified as having a high tax morale and as perceiving a high degree of financial insecurity if they had reported the two highest categories in the questionnaire (i.e., 'strongly agree' $=5$ or 'mildly agree' $=4$ on the 5 -point scale).

${ }^{11}$ For a theoretical model in which occupational choice depends on risk attitudes, see Pestieau and Possen (1991).
} 
future of not paying taxes today to choose to work in the informal sector, while those who perceive a high degree of financial insecurity to work in the formal sector. The former benefit financially from not paying taxes today and do not perceive any future consequences of this choice, either because they may not understand the financial consequences or because they may have other means to provide for themselves in the future. For the individuals who perceive a high degree of financial insecurity, the public insurance schemes are the only source of social safety net, which they can have access to if they work in the formal sector. We ran a Probit regression to explain the individual probability of working in the informal sector by individual perception of financial insecurity. The results show that one's perception of financial insecurity related to not paying taxes has a very small and insignificant effect on the probability of working in the informal sector (a coefficient of 0.059 with a $t$-value of 1.25$).{ }^{12}$ In other words, whether an individual perceives a low or high degree of financial insecurity related to not paying taxes does not have any influence on her or his decision to work in the informal sector. This indicates that individuals do not self-select into one of the two sectors.

A second potential type of supply side endogeneity would occur if individuals' participation in the informal sector may depend on income-earnings' options elsewhere (even when individuals do not freely self-select into one sector). We have two variables to test for this in our data set, namely: the number of household members who have a paid job (or a dummy variable indicating that there is more than one household member working), and the number of family members living abroad who financially support the individual. One would expect that individuals without alternative sources of income would have a higher probability to be in the informal sector. A probit analysis of the probability of working in the informal sector however shows that the effect of both variables is statistically insignificant.

Finally, a third source of sample selection bias may be driven by the demand side. For example, when individuals with certain characteristics, such as low education and skills, are chosen less often to work in the formal sector. Looking at our sample we cannot exclude this option as people with higher education have a statistically significantly lower probability to be working in the informal sector. This may lead to an inconsistent estimate of the effect of informal sector on financial satisfaction if education influences both working in the informal sector and the level of financial satisfaction. This would be the case if lower educated individuals not only have a higher probability of working in the informal sector but also have a set of unobservable characteristics (such as reduced social network and capacity to deal with adversities) that correlate negatively with financial satisfaction. One would correct for this possible source of endogeneity by using instrumental variables. ${ }^{13}$ Some studies use human capital characteristics to estimate both the selection mechanism and the main equation. They do that by using different specifications of the education variables, which may lead to biased results (Dustmann and van Soest 1998). Moreover, it is difficult to believe that education does not affect financial satisfaction in other ways than through the probability of working in the formal sector. Thus, as Dustmann and van Soest (1998) conclude regarding selection between private and public sector: "...correcting for nonrandom selection is important, but is only useful if appropriate instrumental variables are available which play a role in the selection mechanism, but can be excluded from the wage equation." (p. 1419). Apart from education, other authors have instrumented sector choice by, among others, the region of origin, gender, age, number of children and other household structure variables (Gindling 1991; Magnac

\footnotetext{
12 Details are available upon request.

13 If we were to have panel data, we would have used fixed effects to partly correct for the endogeneity.
} 
1991). In our data set, many of these variables proved not to have any effect on sector selection. In addition, age, gender and being married suffer from the same weaknesses as education. One could also exploit geographic variation (see Beuran and Kalugina 2006), time variation (de Holanda and Filho 2005), or information on parent's occupation or education (e.g., Dustmann and Van Soest 1998). Given the cross-sectional nature of our data set and its restriction to individuals located in only one region, we do not possess such instruments.

Therefore, the best we can do is to look at the effect of working in the informal sector on financial satisfaction while controlling for those observable characteristics that differ between individuals in the formal and informal sector. Apart from having lower education, being a woman, older, and having emigrating to Tirana from rural areas also increase the probability of being in the informal sector. These variables will be included in the financial satisfaction equation.

\subsection{Data}

The analysis is based on data collected in a field survey conducted by one of the authors in 2000, in the urban area of Tirana, the capital of Albania. The method applied is the 'selfadministered questionnaire', which combines personal contacts with written questionnaires. The survey sample consisted of 1,500 households living in Tirana, which represented about $1.1 \%$ of Tirana households in 2000 . The sampling was random and based on a geographical framework, covering the five -more or less equally sized- regions of urban Tirana. The main income earner of the household was asked to respond to all the questions. The response rate of $89.3 \%$ gave 1,340 valid questionnaires returned. ${ }^{14}$ For a more detailed description of the data collection method, see Gërxhani (2007). She discusses the representativeness of the data collected by comparing its results to the most recent survey available with comparable data by the Albanian Institute of Statistics (INSTAT). From the comparison, it appears that the average age of the respondents, average size of the household, percentage of children in the household, and gender division of adult members in the household are very similar in the two surveys. Hence, it is concluded that the data collected in 2000 are to a large extent representative of Tirana households.

The data contain information about individual self-reported financial satisfaction on a $0-10$ scale. The sample average equals 3.37 , which is very low compared to the two most well known data sets utilizing this question, that is, financial satisfaction scores in the United Kingdom and Germany (see van Praag and Ferrer-i-Carbonell 2004, Chap. 3). However, the low score of Financial Satisfaction in Albania compares very well to the level of subjective welfare reported in the Albanian LSMS data set of the World Bank (2003). According to this data set, about $80 \%$ of the respondents in Tirana reported to be either 'not at all satisfied' or 'less than satisfied' with their financial situation.

Our data set also provides information on the sector in which individuals work. This is used to distinguish between individuals working in the formal and informal sectors. Respondents were asked to report the sector they work in from a list of seven categories (e.g., public sector, private sector (with and without labor contract), and own business). This information was combined with other available information on reported tax payments (e.g., (non)payment of personal income tax or small business tax). The result is a dummy variable indicating whether an individual works in the formal or informal sector. ${ }^{15}$

\footnotetext{
14 The complete questionnaire can be found in Gërxhani $(2002,2007)$ and will be provided upon request.

15 Individuals are classified as working in the formal sector if: (1) they work in the state sector; (2) they work in their own business and they declare to pay taxes; (3) they work in their family business and they
} 
Individuals are classified as working in the informal sector if: (1) they work in their own business and they do not pay taxes; (2) they work in their family business and they do not pay taxes; (3) they work in the private sector without a labor contract; (4) they do occasional work and they do not pay taxes; and (5) they do other work and do not pay taxes. In the sample, $24.6 \%$ of the respondents work in the informal sector. ${ }^{16}$ Individuals with more than one job (this is $13 \%$ of the sample) are classified as working in the formal sector if at least one of their jobs is in this sector. ${ }^{17}$ In addition, the data contain information on individuals' socio-economic and demographic characteristics (e.g., age, gender, and education), household monthly net income, taxes, and other information relevant for a transition country like Albania (e.g., the number of family members living abroad who supports the family financially). Finally, the data provide information on individual attitudes to various statements related to paying taxes. Two of these attitudinal questions are used to study the importance of perceived financial insecurity and tax morale in explaining the relationship between working in the (in)formal sector and financial satisfaction (cf. Sect. 2.3). In a study of tax evasion, Gërxhani (2004a) uses these and other questions as a measure of informal institutions. For the descriptive statistics of the variables used in the analysis, see Table 2 in the Appendix.

\section{Results}

The presentation of the results is split in two parts. First, financial satisfaction is explained by whether or not an individual works in the informal sector, by the household monthly net income, and by a large set of socio-economic and demographic variables (cf. Eq. 1). Second, the analysis proceeds by distinguishing between various groups of individuals based on their perceived financial insecurity related to not paying taxes and their tax morale (cf. Eq. 2). In addition, the individual financial satisfaction related to working in the informal sector is evaluated in terms of income.

\subsection{Financial Satisfaction and the (in)formal Sector}

Table 1 presents the estimation results for Eq. 1 (specification 1 in the table). These are to a large extent consistent with the existing literature on countries in transition (see Ravallion and Lokshin 2002; van Praag and Ferrer-i-Carbonell 2004). On the one hand, the explanatory variables 'male', 'married', 'higher education', and 'net family income' have a positive coefficient, although 'male' non-significantly so. On the other hand, the coefficients for 'having children' and 'family size' show a negative sign, although the last coefficient is non-significant.

Albania has its own particularities, however, which relate to its phase of development. They involve the following: the effect of having (and being financially supported by)

Footnote 15 continued

declare to pay taxes; (4) they work in the private sector with a labor contract; (5) they do occasional work and they declare to pay taxes; and (6) they do other work and declare to pay taxes.

16 Note that there are no other comparable data sources that measure the underground economy in Albania through informal employment.

17 This is because by having at least one job in the formal sector, they have the right to social benefits. The regression analysis (below) corrects, nevertheless, for having more than one job by including a dummy variable ('moonlighting'), which takes value 1 if an individual has more than one job and 0 otherwise. Note that classifying these individuals as being in the informal sector produces qualitatively very similar results to the ones presented here. 
Table 1 Financial satisfaction albania, OLS

\begin{tabular}{|c|c|c|c|c|c|c|}
\hline & \multicolumn{2}{|l|}{ Specif. 1} & \multicolumn{2}{|l|}{ Specif. 2} & \multicolumn{2}{|l|}{ Specif. 3} \\
\hline & Coeff. & $t$ & Coeff. & $t$ & Coeff. & $t$ \\
\hline Constant & $-7.540(1.55)$ & -4.86 & $-7.029(1.66)$ & -4.24 & $-6.431(1.64)$ & -3.93 \\
\hline Male & $0.186(0.17)$ & 1.12 & $0.284(0.17)$ & 1.70 & $0.289(0.17)$ & 1.73 \\
\hline Ln(Age) & $-0.239(0.35)$ & -0.68 & $-0.346(0.35)$ & -0.98 & $-0.344(0.35)$ & -0.98 \\
\hline Individual is married & $1.075(0.33)$ & 3.26 & $1.052(0.33)$ & 3.19 & $1.066(0.33)$ & 3.23 \\
\hline Individual has children & $-1.011(0.28)$ & -3.63 & $-0.964(0.28)$ & -3.44 & $-0.989(0.28)$ & -3.53 \\
\hline Ln(Family size) & $-0.287(0.24)$ & -1.20 & $-0.248(0.24)$ & -1.03 & $-0.236(0.24)$ & -0.98 \\
\hline Individual has higher education & $0.485(0.15)$ & 3.30 & $0.473(0.15)$ & 3.19 & $0.488(0.15)$ & 3.29 \\
\hline $\begin{array}{l}\text { Migration from North or South to } \\
\text { Tirana }\end{array}$ & $-0.101(0.16)$ & -0.62 & $-0.119(0.16)$ & -0.74 & $-0.111(0.16)$ & -0.68 \\
\hline Migration from rural to Tirana & $0.42(0.23)$ & 1.86 & $0.232(0.23)$ & 1.02 & $0.238(0.23)$ & 1.04 \\
\hline Working in the Informal sector & $-0.139(0.17)$ & -0.83 & $1.999(0.98)$ & 2.05 & $-0.081(0.17)$ & -0.48 \\
\hline $\begin{array}{l}\text { Informal } \times \text { Perceived financial } \\
\text { insecurity }\end{array}$ & & & $-0.430(0.19)$ & -2.25 & & \\
\hline Perceived financial insecurity & & & $-0.044(0.10)$ & -0.43 & $-0.172(0.09)$ & -1.97 \\
\hline Informal $\times$ Tax morale & & & $-0.047(0.15)$ & -0.32 & & \\
\hline Tax morale & & & $-0.201(0.09)$ & -2.30 & $-0.216(0.07)$ & -3.01 \\
\hline $\begin{array}{l}\text { Moonlighting: having more than } \\
\text { one job }\end{array}$ & $0.308(0.20)$ & 1.51 & $0.346(0.21)$ & 1.67 & $0.332(0.21)$ & 1.60 \\
\hline $\begin{array}{l}\text { Ln(Number of family members } \\
\text { working) }\end{array}$ & $0.281(0.20)$ & 1.42 & $0.287(0.20)$ & 1.42 & $0.290(0.20)$ & 1.43 \\
\hline Ln(Number of (family) emigrants) & $0.765(0.33)$ & 2.34 & $0.924(0.34)$ & 2.72 & $0.900(0.34)$ & 2.64 \\
\hline Ln(Net family income) & $1.144(0.09)$ & 13.43 & $1.170(0.09)$ & 13.05 & $1.170(0.09)$ & 13.03 \\
\hline Observations & 908 & & 880 & & 880 & \\
\hline$R^{2}$ & 0.229 & & 0.246 & & 0.242 & \\
\hline
\end{tabular}

Note: standard deviations are in parentheses

family members living abroad is positive on individual financial satisfaction; having lived in a rural area before transition also affects financial satisfaction positively (this may capture a comparison effect with the past); and having more than one job also has a positive coefficient (although only significant at $13.1 \%$ ).

Finally, the empirical analysis shows that the coefficient for working in the informal sector is negative but not statistically significant. Below we show that this non-significant coefficient is a weighted average across two groups of individuals for whom working in the informal sector has a different impact on their financial satisfaction. By correcting for individuals' perception of their financial insecurity related to not paying taxes, the effect of working in the informal sector on financial satisfaction becomes statistically strong and negative.

\subsection{Financial Satisfaction, Perceived Financial Insecurity and Tax Morale}

The second specification (fourth and fifth columns) of Table 1 presents the estimation results for Eq. 2. ${ }^{18}$ The interaction between working in the informal sector and perceived financial insecurity has a negative and statistically significant effect, which means that for

${ }_{18}$ Note that the coefficients of variables included in both equations are almost identical. 
individuals working in the informal sector there is a negative relationship between financial satisfaction and agreeing with the statement that not paying taxes today has financial consequences in the future. As for individuals who do not perceive a high degree of financial insecurity (i.e., the ones who 'strongly disagree' that not paying taxes today has consequences for the future), the results show that working in the informal sector correlates positively with financial satisfaction. The total coefficient for the majority of individuals (82\% of the sample) who perceive the highest degree of financial insecurity due to not paying taxes (i.e., the ones who report a 5 (='strongly agree')) is $-0.150(=1.999+$ $(-0.430 \times 5))$. The impact of working in the informal sector on financial satisfaction is positive for all the other individuals (18\% of the sample), the ones who report anything else than 'strongly agree' (i.e., from 'mildly agree' to 'strongly disagree'). ${ }^{19}$

We can thus conclude that specification 1 was unable to distinguish between different types of individuals whose effect of working in the informal sector on their financial satisfaction is distinct. The effect of the variable indicating the degree of perceived financial insecurity is insignificant and very small. It is only through the interaction with the sector in which one works that perceived financial insecurity affects individual financial satisfaction.

The coefficient of the interaction term between working in the informal sector and tax morale is very small and non-significant, indicating that the effect of working in the informal sector on financial satisfaction does not seem to depend on individuals' morale about contributing to society through taxes (i.e., public goods). The coefficient of tax morale is however negatively correlated with financial satisfaction. This implies that the higher the tax morale, the less satisfied individuals are with their financial situation, regardless of whether they work in the formal or informal sector. For individuals working in the formal sector, it seems that the economic burden of paying taxes outweighs the 'warm glow' effect of contributing to others' well-being. As hypothesized, individuals working in the informal sector and having a high tax morale are financially less satisfied because they are unable to contribute to the society through taxes. ${ }^{20}$

Finally, the third specification of Table 1 shows that including the two variablesperceived financial insecurity and tax morale- without the interaction terms generates similar results as specification (1).

The importance of the correlation between financial satisfaction and working in the informal sector (for individuals who perceive a high degree of financial insecurity) can also be evaluated in terms of income by calculating the compensating income and the income equivalent of working in the formal sector (for similar approaches see Ferrer-i-Carbonell and van Praag 2002; Blanchflower and Oswald 2004).

From Eq. 2 we can derive the income necessary to compensate an individual who perceives the highest degree of financial insecurity (i.e., reporting a 5 (='strongly agree') for the loss of satisfaction due to working in the informal sector:

$$
\Delta \ln y=\frac{\gamma+(5 \times \varphi)}{\beta}-1 \Rightarrow \Delta y=\exp \left(\frac{\gamma+(5 \times \varphi)}{\beta}\right)-1
$$

\footnotetext{
${ }^{19}$ We performed a robustness check and found that the results in specification 2 do not change when excluding 'tax morale' from the regression.

${ }^{20}$ Other studies have looked at the effect of financial satisfaction on tax morale and have empirically found that a higher level of financial satisfaction leads to a higher level of tax morale or willingness to pay taxes (for an extensive overview, see Torgler 2007).
} 
The equivalent loss is the reciprocal of the compensating income. Applying the estimated coefficients in Table 1 (specification 2) to this equation we find that by moving from the formal to the informal sector an individual who perceives a high degree of financial insecurity would experience a satisfaction loss equivalent to $12 \%$ of his or her income. The (compensating) income necessary to bring this individual back to the initial level of satisfaction is a $19.2 \%$ income increase. These results show the economic relevance for financial satisfaction of moving from the formal to the informal sector.

In summary, the results show that the effect of working in the (in)formal sector on financial satisfaction (after controlling for income and other variables), can be attributed to the individual perception of financial insecurity related to not paying taxes. For individuals working in the informal sector, the higher (lower) the degree of perceived financial insecurity, the lower (higher) is their financial satisfaction.

\section{Conclusion}

Comparative studies of individuals working in the formal and informal sectors have mainly focused on the income differential between the two sectors. Even when other aspects like ease of entry and social exclusion are theoretically recognized, it has remained an open question what the effect of working in the formal or informal sector is on an individual's welfare. ${ }^{21}$ This paper adds to the literature by providing an empirical answer to this question. We were able to do that by using a subjective welfare measurement, i.e., financial satisfaction. More specifically, we focus on the relationship between working in the formal or informal sector and financial satisfaction in a country in transition. In addition to an informal sector of a larger magnitude, it has long been argued that this sector plays a role in these countries that is much different than its role in developed countries. In particular, the informal sector in transition countries provides a route towards survival for individuals who are unable to find employment in the formal sector (Gërxhani 2004b).

When considering the effect of the sector on the (self-reported) financial satisfaction we observe that for most individuals, working in the informal sector has negative effects on their subjective welfare. However, some individuals who work in the informal sector are financially even more satisfied than their counterparts in the formal sector. We are able to explain this dichotomy by distinguishing between two types of individuals based on their perceived financial insecurity and their tax morale. The differentiating characteristic of the individuals who are more satisfied in the informal sector is that they perceive a low degree of financial insecurity, i.e., they disagree that not paying taxes today has personal financial repercussions in the future. It is likely that these individuals have other means to provide for themselves in the future, for example through family or accumulated wealth. As such, they report a high financial satisfaction because they do not mind being excluded from public insurance by working in the informal sector. For other individuals, representing the majority of the individuals working in the informal sector, public insurance schemes like social security may be the only source of social safety net in the future. By working in the

\footnotetext{
${ }^{21}$ For example, in their study on Nicaragua, Pisani and Pagán (2003) presume that the willingness to queue for a formal sector job might be related to pecuniary and nonpecuniary benefits associated with the formal sector jobs that matter to informal sector workers.
} 
informal sector they are automatically excluded from these mechanisms, which makes them financially less satisfied.

By focusing on subjective measures, we are able to capture effects that cannot be observed if comparisons are based only on wage differentials as the classical models of formal-informal wage dualism claim (see Harris and Todaro 1970; Bardhan and Rudra 1981; Fields 1975 onwards). As shown in this paper, the impact of the working sector on individual welfare goes beyond income. This impact is of a particular importance for transition countries with large informal sectors. Given the involuntary participation in the informal sector in these countries, the majority of individuals working in this sector will remain financially unsatisfied as long as they have no other source of social safety. An important implication is that policies aiming at welfare improvement and social equality, should either try to increase the number of jobs available in the formal sector, such that individuals can voluntary choose in which sector to work or at least make sure that individuals who are forced to work in the informal sector are aware of the financial consequences for their future pensions. In both cases, an alternative private system of individually building up a pension should be available and accessible by every individual, irrespective of the sector they work in.

Acknowledgments We would like to thank Jordi Brandts, Bruno Frey, Erik Plug, Arthur Schram, Jeroen van den Bergh, Bernard van Praag, two anonymous referees and the editor for useful comments and support.

Open Access This article is distributed under the terms of the Creative Commons Attribution Noncommercial License which permits any noncommercial use, distribution, and reproduction in any medium, provided the original author(s) and source are credited.

\section{Appendix}

Table 2 Summary statistics

\begin{tabular}{|c|c|c|c|c|}
\hline Variable & Mean & SD & Min & $\operatorname{Max}$ \\
\hline Male & 0.754 & 0.431 & 0 & 1 \\
\hline Ln(Age) & 3.743 & 0.219 & 2.833 & 4.304 \\
\hline Individual is married & 0.910 & 0.287 & 0 & 1 \\
\hline Individual has children & 0.866 & 0.341 & 0 & 1 \\
\hline Ln(Family size) & 1.426 & 0.332 & 0 & 2.485 \\
\hline Individual has higher education & 0.454 & 0.498 & 0 & 1 \\
\hline Migration from North or South to Tirana & 0.334 & 0.472 & 0 & 1 \\
\hline Migration from rural to Tirana & 0.141 & 0.348 & 0 & 1 \\
\hline Working in the Informal sector & 0.246 & 0.431 & 0 & 1 \\
\hline Perceived financial insecurity & 0.904 & 0.294 & 0 & 1 \\
\hline Tax morale & 0.823 & 0.382 & 0 & 1 \\
\hline Moonlighting: having more than one job & 0.134 & 0.341 & 0 & 1 \\
\hline Ln(Number of family members working) & 0.180 & 0.368 & 0 & 2.197 \\
\hline Ln(Number of (family) emigrants) & 0.045 & 0.211 & 0 & 1.792 \\
\hline Ln(Net family income) & 10.333 & 0.828 & 0 & 13.122 \\
\hline No. of observations & 908 & & & \\
\hline
\end{tabular}




\section{References}

Allingham, M. G., \& Sandmo, A. (1972). Income tax evasion: A theoretical analysis. Journal of Public Economics, 1, 323-338.

Alm, J., Martinez-Vazquez, J., \& Torgler, B. (2006). Russian attitudes toward paying taxes-before, during, and after the transition. International Journal of Social Economics, 33, 832-857.

Alm, J., McClelland, G. H., \& Schulze, W. D. (1992). Why do people pay taxes? Journal of Public Economics, 48, 21-38.

Alm, J., Sanchez, I., \& de Juan, A. (1995). Economic and noneconomic factors in tax compliance. Kyklos, 48, 3-18.

Alm, J., \& Torgler, B. (2005). Estimating the determinants of tax morale. National Tax Association Papers and Proceedings (Minneapolis 2004) 269-274.

Alm, J., \& Torgler, B. (2006). Culture differences and tax morale in the United States and Europe. Journal of Economic Psychology, 27, 224-246.

Andreoni, J. (1990). Impure altruism and donations to public goods: A theory of warm-glow giving. The Economic Journal, 100(401), 464-477.

Banerjee, N. (1982). Survival of the poor. In H. I. Safa (Ed.), Towards a political economy of urbanization in third world countries (pp. 175-188). Delhi: Oxford University Press.

Bardhan, P. K., \& Rudra, A. (1981). Terms and conditions of labour contracts in agriculture: Results of a survey in West Bengal 1979. Oxford Bulletin of Economics and Statistics, 43, 89-111.

Becker, W., Büchner, H.-J., \& Sleeking, S. (1987). The impact of public transfer expenditures on tax evasion: An experimental approach. Journal of Public Economics, 34, 243-252.

Beqja, I. (2002). Restructuring of the pension system in South Eastern Europe. Ljubljana: Working paper.

Beuran, M., \& Kalugina, E. (2006). Social exclusion and the informal sector: the case of Russia. Work in progress Centre d'Economie de la Sorbonne, Université de Paris 1.

Bird, R. M., Martinez-Vazquez, J., \& Torgler, B. (2008). Tax Effort in developing countries and high income countries: The impact of corruption, voice and accountability. Economic Analysis \& Policy, 38, 55-71.

Blanchflower, D., \& Oswald, A. J. (2004). Well-being over time in Britain and the USA. Journal of Public Economics, 88, 1359-1386.

Bourguignon, F. (1979). Pobreza y dualismo en el sector urbano de las economias en Desarrollo: El Caso de Colombia. January: Desarrollo y Sociedad.

Bradburn, N. M. (1969). The structure of psychological well-being. Chicago: Aldine Publishing Company.

Cantril, H. (1965). The pattern of human concerns. New Brunswick: Rutgers University Press.

Charmes, J. (1990). A critical review of concepts, definitions and studies in the informal sector. In D. Turnham, B. Salome, \& S. Schwarz (Eds.), The informal sector revisited (pp. 10-49). Paris: OECD.

Clark, A. E., \& Oswald, A. J. (1994). Unhappiness and unemployment. Economic Journal, 104, 648-659.

Cowell, F. (1990). Cheating the Government. Cambridge: MIT Press.

Cummings, R., Martinez-Vazquez, J., McKee, M., \& Torgler, B. (2009). Effects of tax morale on tax compliance: Experimental and survey evidence. Journal of Economic Behavior and Organization, 70, 447-457.

De Grazia, R. (1982). Clandestine employment: A problem of our times. In V. Tanzi (Ed.), The underground economy in the United States and abroad. Lexington, DC: Heath.

de Holanda, F. \& Filho, B. (2005). Labor legislation and the size of informal sector in Brazil. Working paper.

DiTella, R., MacCulloch, R. J., \& Oswald, A. J. (2001). Preferences over inflation and unemployment: Evidence from surveys of subjective well-being. American Economic Review, 91, 335-341.

Dustmann, C., \& Van Soest, C. (1998). Public and private sector wages of male workers in Germany. European Economic Review, 42, 1417-1441.

Easterlin, R. A. (2001). Income and happiness: Towards a unified theory. The Economic Journal, 111, 465-484.

Feige, E. L. (1990). Defining and estimating underground and informal economies: The new institutional economics approach. World Development, 18(7), 989-1002.

Feld, L. P., \& Frey, B. S. (2002). Trust breeds trust: How taxpayers are treated. Economics of Governance, 3, 87-99.

Feld, L., \& Torgler, B. (2006). Tax morale in Germany in the 90s. National Tax Association Papers and Proceedings, 195-203.

Ferrer-i-Carbonell, A. (2005). Income and well-being: An empirical analysis of the comparison income effect. Journal of Public Economics, 89, 997-1019. 
Ferrer-i-Carbonell, A., \& Frijters, P. (2004). How important is methodology for the estimates of the determinants of happiness? The Economic Journal, 114, 641-659.

Ferrer-i-Carbonell, A., \& van Praag, B. M. S. (2002). The subjective costs of health losses due to chronic diseases. An alternative model for monetary appraisal. Health Economics, 11, 709-722.

Fields, G. S. (1975). Rural-urban migration, urban unemployment and underemployment, and job search activity in LDC's. Journal of Development Economics, 2, 165-188.

Fields, G. S. (1990). Labor market modeling and the urban informal sector: Theory and evidence. In D. Turnham, B. Salome, \& S. Schwarz (Eds.), The informal sector revisited (pp. 49-69). Paris: OECD.

Frey, B. S. (1989). How large (or small) should the underground economy be? In E. L. Feige (Ed.), The underground economy: Tax evasion and information distortion (pp. 111-129). pp: Cambridge University Press.

Frey, B. S., \& Stutzer, A. (2002). What can economists learn from happiness research? Journal of Economic Literature, 40, 402-435.

Frey, B. S., \& Torgler, B. (2007). Tax morale and conditional cooperation. Journal of Comparative Economics, 35, 136-159.

Frijters, P., Haisken-DeNew, J. P., \& Shields, M. A. (2004). Money does matter! Evidence from increasing real incomes and life satisfaction in East Germany following reunification. American Economic Review, 94(3), 730-741.

Garner, T. I., \& Short, K. S. (2003). Personal assessments of minimum income and expenses: What do they tell us about 'minimum living' thresholds and equivalence scales? In Y. Amiel \& J. S. Bishop (Eds.), Inequality, welfare and povery: Theory and measurement (Vol. 9). Elsevier Science: The Netherlands.

Gërxhani, K. (2002). The informal sector in transition: Tax evasion in an institutional vacuum, Ph.D. thesis, University of Amsterdam, Tinbergen Institute Research Series, no. 265, University of Amsterdam, Amsterdam.

Gërxhani, K. (2004a). Tax evasion in transition: Outcome of an institutional clash? Testing Feige's conjecture in Albania. European Economic Review, 48, 729-745.

Gërxhani, K. (2004b). The informal sector in developed and less developed countries: A literature survey. Public Choice, 120(3-4), 267-300.

Gërxhani, K. (2007). "Did you pay your taxes?" How (not) to conduct tax evasion surveys in transition countries. Social Indicators Research, 80, 555-581.

Gërxhani, K., \& Schram, A. (2006). Tax evasion and income source: A comparative experimental study. Journal of Economic Psychology, 27(3), 402-422.

Gindling, T. H. (1991). Labor market segmentation and the determination of wages in the public, privateformal, and informal sectors in San Jose, Costa Rica. Economic Development and Cultural Change, 39, 585-606.

Gustafsson, B., Shi, L., \& Sato, H. (2004). Can a subjective poverty line be applied to china? Assessing poverty among urban residents in 1999. Journal of International Development: 16, 1089-1107.

Hansson, I. (1982). The Underground economy in a high tax country: The case of Sweden. In V. Tanzi (Ed.), The underground economy in the United States and abroad. Lexington, DC: Heath.

Harris, J., \& Todaro, M. (1970). Migration, unemployment, and development: A two sector Analysis. American Economic Review, 40, 126-142.

Heckman, J. J., \& Hotz, V. J. (1986). An investigation of the labor market earnings of panamanian males: Evaluating the sources of inequality. Journal of Human Resources, 21, 507-542.

Jung, Y. H., Snow, A., \& Trandel, G. A. (1994). Tax evasion and the size of the underground economy. Journal of Public Economics, 54, 391-402.

Kahneman, D., Diener, E., \& Schwarz, N. (Eds.). (1999). Foundations of hedonic psychology: Scientific perspectives on enjoyment and suffering. New York: Russell Sage Foundation.

Kapteyn, A. (1994). The measurement of household cost functions: Revealed preference versus subjective measures. Journal of Population Economics, 7, 333-350.

Kapteyn, A., Kooreman, P., \& Willemse, R. J. (1988). Some methodological issues in the implementation of subjective poverty definitions. Journal of Human Resources, 23, 222-242.

Kesner-Skreb, M. (1997). The unofficial economy and development. Paper presented in the international workshop. 'The importance of unofficial economy in economic transition. Zagreb, Croatia, May 16-17, 1997.

Kugler, B., Reyes, A., \& de Gomez, M. I. (1979). Educacion y Mercado de Trabajo Urbano en Colombia. Bogota, Corporacion Centro regional de Poblacion. In G. S. Maddala (Ed.), Limited-dependent and qualitative variables in econometrics (1983). Cambridge, UK: Cambridge University Press.

Maddala, G. (1983). Limited-dependent and qualitative variables in econometrics. Cambridge: Cambridge University Press.

Magnac, T. (1991). Segmented or competitive labor markets. Econometrica, 59, 165-187. 
Marcouiller, D., de Castilla, V. R., \& Woodruff, C. (1997). Formal measures of the informal-sector wage gap in Mexico, El Salvador, and Peru. Economic Development and Cultural Change, 45, 367.

Merrick, T. W. (1976) Employment and earnings in the informal sector in Brazil: The case of Belo Horizonte. Journal of Developing Areas, 10, 337-354.

Ng, Y.-K. (1997). A case for happiness, Cardinalism, and interpersonal comparability. The Economic Journal, 107, 1848-1858.

Oswald, A. J. (1997). Happiness and economic performance. The Economic Journal, 107, 1815-1831.

Pestieau, P., \& Possen, U. M. (1991). Tax evasion and occupational choice. Journal of Public Economics, 45, 107-125.

Pisani, M. J., \& Pagán, J. A. (2003). Sectoral queuing in a transitional economy: The case of Nicaragua in the 1990 s. Labour, 17, 571-597.

Pradhan, M., \& Ravallion, M. (2000). Measuring poverty using qualitative perceptions of consumption adequacy. Review of Economics and Statistics, 82, 462-471.

Pradhan, M., \& van Soest, A. (1995). Formal and informal sector employment in urban areas of Bolivia. Labour Economics, 2, 275-297.

Ravallion, M., \& Lokshin, M. (2002). Self-rated economic welfare in Russia. European Economic Review, 46, 1453-1473.

Renooy, P. H. (1990). The informal economy: Meaning, measurement and social significance. Amsterdam: Netherlands Geographical Studies.

Schneider, F. (2005). Shadow economies around the world. What do we really know? European Journal of Political Economy, 21, 598-642.

Schneider, F., \& Enste, D. H. (2000). Shadow economies: Size, causes and consequences. Journal of Economic Literature, 38(1), 77-114.

Schneider, F., \& Enste, D. H. (2003). The shadow economy: An international survey. Cambridge: Cambridge University Press.

Schroyen, F. (1997). Pareto efficient income taxation under costly monitoring. Journal of Public Economics, $65,343-366$.

Senik, C. (2005). What can we learn from subjective data? The case of income and well-being. Journal of Economic Surveys, 19, 43-63.

Thomas, J. J. (1990). Synthesis of comments and discussion: Methodology and theory. In D. Turnham, B. Salome, \& S. Schwarz (Eds.), The informal sector revisited. Paris: OECD.

Torgler, B. (2003). Tax morale in transition countries. Post-communist Economies, 15, 357-381.

Torgler, B. (2007). Tax compliance and tax morale: A theoretical and empirical analysis. Cheltenham, UK: Edward Elgar Publishing.

Torgler, B., \& Schneider, F. (2007). What shapes attitudes towards paying taxes? Evidence from multicultural European countries. Social Science Quarterly, 88, 443-470.

Torgler, B., \& Schneider, F. (2009). The impact of tax morale and institutional quality on the shadow economy. Journal of Economic Psychology, 30, 228-245.

van Praag, B. M. S. (1971). The welfare function of income in Belgium: An empirical investigation. European Economic Review, 2, 337-369.

van Praag, B. M. S., \& Ferrer-i-Carbonell, A. (2004). Happiness quantified: A satisfaction calculus approach. Oxford, UK: Oxford University Press.

van Praag, B. M. S., Flik, R. J., \& Stam, P. J. A. (1997). Poverty lines and equivalence scales: Aa theoretical and empirical evaluation. In N. Keilman, H. B. Lyngstad, \& I. Thomsen (Eds.), Poverty and economic inequality in industrialized Western Societies. Oslo: Scandinavian UP.

van Praag, B. M. S., \& Frijters, P. (1999). The measurement of welfare and well-being; the Leyden approach. In D. Kahneman, E. Diener, \& N. Schwarz (Eds.), Foundations of hedonic psychology: Scientific perspectives on enjoyment and suffering. New York: Russel Sage Foundation. Chap. 21.

van Praag, B. M. S., Frijters, P., \& Ferrer-i-Carbonell, A. (2003). The anatomy of well-being. Journal of Economic Behavior \& Organization, 51, 29-49.

Watson, H. S. (1985). Tax evasion and labor markets. Journal of Public Economics, 27, 231-246.

Wilson, W. (1967). Correlates of avowed happiness. Psychological Bulletin, 67, 294-306.

World Bank. (2003). Albania: Poverty assessment. Report no. 26213-AL, The World Bank.

Yitzhaki, S. (1974). Income tax evasion: A theoretical analysis. Journal of Public Economics, 3, $201-202$. 